Meta

Journal des traducteurs

Translators' Journal

\title{
Three Lives of The Saint in Polish Voiceover Translation
}

\section{Agata Hołobut}

Volume 57, numéro 2, juin 2012

La manipulation de la traduction audiovisuelle

The Manipulation of Audiovisual Translation

URI : https://id.erudit.org/iderudit/1013957ar

DOI : https://doi.org/10.7202/1013957ar

Aller au sommaire du numéro

Éditeur(s)

Les Presses de l’Université de Montréal

ISSN

0026-0452 (imprimé)

1492-1421 (numérique)

Découvrir la revue

\section{Citer cet article}

Hołobut, A. (2012). Three Lives of The Saint in Polish Voiceover Translation. Meta, 57(2), 478-495. https://doi.org/10.7202/1013957ar

\section{Résumé de l'article}

Le présent article expose la traduction polonaise d'une série télévisée du point de vue diachronique. Il compare une version avec la voix hors-champ de la série The Saint diffusée par la télévision publique à l'époque du régime communiste avec deux versions plus récentes, réalisées vingt-cinq et trente ans plus tard. Cette comparaison a pour but de mettre en relief les traces d'une manipulation socioculturelle dans l'image de la réalité occidentale créée au fil des années, en particulier les pratiques de traduction à l'époque communiste. La première partie de l'article montre le contexte historique tout en considérant le rôle des émissions dans les premières décennies de l'existence de la télévision polonaise. La deuxième partie se concentre sur les techniques de manipulation telles que la projection, la caricature, la généralisation ou l'omission, dont se sont servis les premiers traducteurs de la série pour adapter le message aux besoins d'une propagande communiste. Des exemples concrets illustrent la manière dont on déformait l'image de la réalité occidentale pour critiquer le matérialisme et l'individualisme, et ainsi promouvoir le collectivisme désintéressé, la lutte des classes et former des attitudes civiques. La dernière partie de l'article fait un bref tour d'horizon des symptômes d'une manipulation socioculturelle dans les traductions plus récentes de la série, manipulation qui résulte du besoin d'adaptation à une nouvelle situation sociale et politique en Pologne.
Ce document est protégé par la loi sur le droit d'auteur. L'utilisation des services d'Érudit (y compris la reproduction) est assujettie à sa politique d'utilisation que vous pouvez consulter en ligne.

https://apropos.erudit.org/fr/usagers/politique-dutilisation/ 


\title{
Three Lives of The Saint in Polish Voiceover Translation
}

\author{
AGATA HOLOBUT \\ Jagiellonian University, Krakow, Poland \\ aholobut@gazeta.pl
}

\begin{abstract}
RÉSUMÉ
Le présent article expose la traduction polonaise d'une série télévisée du point de vue diachronique. Il compare une version avec la voix hors-champ de la série The Saint diffusée par la télévision publique à l'époque du régime communiste avec deux versions plus récentes, réalisées vingt-cinq et trente ans plus tard. Cette comparaison a pour but de mettre en relief les traces d'une manipulation socioculturelle dans l'image de la réalité occidentale créée au fil des années, en particulier les pratiques de traduction à l'époque communiste. La première partie de l'article montre le contexte historique tout en considérant le rôle des émissions dans les premières décennies de l'existence de la télévision polonaise. La deuxième partie se concentre sur les techniques de manipulation telles que la projection, la caricature, la généralisation ou l'omission, dont se sont servis les premiers traducteurs de la série pour adapter le message aux besoins d'une propagande communiste. Des exemples concrets illustrent la manière dont on déformait l'image de la réalité occidentale pour critiquer le matérialisme et l'individualisme, et ainsi promouvoir le collectivisme désintéressé, la lutte des classes et former des attitudes civiques. La dernière partie de l'article fait un bref tour d'horizon des symptômes d'une manipulation socioculturelle dans les traductions plus récentes de la série, manipulation qui résulte du besoin d'adaptation à une nouvelle situation sociale et politique en Pologne.
\end{abstract}

\section{ABSTRACT}

The article adopts a diachronic perspective on Polish screen translation. It compares the voiceover version of the British series The Saint broadcast on public television under the old regime with more recent ones, released twenty-five and thirty years later. The main aim is to analyse traces of socio-cultural manipulation in the consecutive portrayals of the Western reality, with special emphasis on translation practice in the communist era. The first section provides historical background for the research, discussing the role of translated programmes in the first decades of the Polish Television. The second section focuses on manipulative techniques, such as projection, caricature, generalisation and omission, used by the earliest translators of the series to adapt the audiovisual message to the needs of communist propaganda. Specific examples illustrate how the Western reality was distorted to criticise materialism and individualism, promote selfless collectivism and class struggle and shape appropriate civic attitudes. The final section presents a brief overview of symptoms of socio-cultural manipulation in the more recent versions of the series, used to adapt it to the changed socio-political situation in Poland.

\section{MOTS-CLÉS/KEYWORDS}

voix hors-champ, traduction pour la télévision, Pologne, manipulation socioculturelle, communisme voiceover, television translation, Poland, socio-cultural manipulation, communism 


\section{Introduction}

For the past thirty years, scholars have become increasingly interested in the cultural and ideological implications of translation, studying the norms, shifts and values (Toury 1978/2000) involved in the selection and reception of source texts in the target culture (Even-Zohar 1978/2000: 193). These academic pursuits marked a departure from prescriptivism towards descriptivism in the study of translation, characteristic of the late 1970s (Bukowski and Heydel 2009: 21). The former approach placed the centre of gravity in the original and aimed to formulate the laws of equivalence for the satellite-translation to obey. The latter, by contrast, resembled a lunar expedition, organized to explore the translations on their own terms and survey their stylistic topographies, shaped by unique cultural, social and political climate.

Early descriptive studies, conducted by Dutch, Belgian and Israeli scholars of literary persuasion, emphasized the entanglement of translated texts in the artistic, political and economic systems of the recipient culture (Tymoczko 2007: 41). They were viewed as "refractions" (Lefevere 1982/2000: 235) rather than reflections of the original works, adapted to the requirements of professionals (translators, editors, reviewers), patrons (political and economic) and the prevalent poetic trends (Lefevere 1982/2000: 235; Munday 2008: 49).

Recent developments in the descriptive investigations have put even greater emphasis on the ideological issues, in response to the socio-political upheavals at the close of the twentieth century. The fall of communism, the rise of postcolonialism and globalization triggered cultural and power turns in translation studies (Tymoczko 2007: 43-45), bringing to the fore the ethical responsibilities and political tensions involved in representing the Other.

Nowadays, more and more scholars investigate the impact of ideology, political control and censorship on translation practice (Tymoczko 2007: 45). Such an approach seems especially pertinent to the study of film and television translation, directed at a wide audience and hence susceptible to various institutional pressures. Indeed, inspired by Díaz Cintas (2003: 32), Munday (2008: 178) claims that the potential for "real progress" in audiovisual translation research lies in a "systematic close analysis" of film corpora from the point of view of culture, power and ideology, adopted so far in the "mainstream" translation studies.

My article follows these suggestions, looking into the history of Polish television translation. This more than 50-year history is worth examining in terms of "refraction," as it documents the country's transition from communism to democracy and the evolution of an idiosyncratic voiceover technique, with a single male voice-artist interpreting both fiction and non-fiction programmes (for a discussion of Polish voiceover see for example Garcarz [2007], Tomaszkiewicz [2008], Woźniak [2008]). Hence, it has both socio-cultural and stylistic manipulation in its genes, adapting the audiovisual messages to the changing needs of the Polish audience and the requirements of the voiceover transfer.

I will concentrate below on the former phenomenon, comparing the voiceover version of the British cult series The Saint (1962-1969) ${ }^{1}$ broadcast under the communist regime with the versions released twenty-five and thirty years later. I will attempt to detect and diagnose symptoms of socio-cultural manipulation in the way new generations of translators portrayed the Western reality, which may have seemed reactionary in the communist era and old-fashioned in the new millennium. 


\subsection{Small screen behind the Iron Curtain}

So far surprisingly neglected, I would argue that television translation in the countries of the former Soviet Bloc deserves academic attention as a cultural byproduct of the Cold War. Behind the Iron Curtain, the new medium was not intended as a source of light entertainment, but a tool of social engineering. Only politically correct programmes were allowed on air, most of them produced in the socialist camp. Western imports were scarce and anachronistic. But the question of the degree and forms of manipulation involved in their translation is certainly worth addressing.

With this intention in mind, I examine the strategies used in the communist era to translate films that portrayed contemporary Western reality, poles apart from the poverty-stricken life in the Polish People's Republic. I am interested in how the translators rendered references to products, places, social relations and customs alien to the Polish audience. From among the few foreign productions available at the time, I chose the British cult series The Saint, which enjoyed spectacular popularity among Polish viewers in the 1960 s and 1970 s. $^{2}$ As it was broadcast several times under the communist regime, I suspected its consecutive translations to involve various manipulative techniques used to tone down the optimism and prosperity exuding from the screen. I hoped that these interventions would become all the more apparent when contrasted with two contemporary voiceover versions: one prepared for the same state television channel at the beginning of the new millennium ${ }^{3}$ and the other available on DVD. ${ }^{4}$

As it turned out, however, almost no trace of the first translations is left in the Polish Television archives. Only three episodes have survived, dated 1976. Still, the preserved files give a fascinating insight into the methods of television translation in the communist era. Before commenting on them in detail, let us sketch the sociocultural background from which the analysed material emerged.

\subsection{Polish Television}

In the Soviet Bloc countries, television was conceived as a tribune of the Marxist ideology and an educator of the working classes. The Soviet Union was the first country in Europe to commence regular transmission in July 1945 (Kozieł 2003: 15). All satellite states, including Poland, emphasised its pioneering role in the development of the new medium and undertook efforts to launch their own national television. According to the Stalinist propaganda of the 1950s, it was to serve a strictly ideological and educational function "facilitating the work of scientists, deep-sea divers, foundry workers and other intellectuals" (Kozieł 2003: 17; my translation).

The Polish national television broadcast its inaugural programme on 25 October 1952. Like all media, it was owned by the ruling party and considered a "tool of its political authority" (Kozieł 2003: 7; my translation). Both fact and fiction were vested with the same educational and ideological mission.

In the first year of its existence, Polish television broadcast only a thirty-minute programme once a week. With time, the format expanded and the communist control grew tighter, precluding improper artistic and ideological choices (Kozieł 2003: 40). According to the media historian Andrzej Kozieł, foreign films were initially aired in their cinema versions, with subtitles barely visible on the small screens. In 
1959 Polish television made the first ever independent purchase of 74 French and 20 Anglophone films and was faced with the necessity of choosing the best translation method. As the historian argues, after some controversy, both subtitling and dubbing were ruled out as too expensive and the voiceover technique was officially adopted as the golden mean (Kozieł 2003: 40).

In the 1960s, television was vested with a new mission of cementing the Eastern Bloc against its Western adversaries and censorship blocked information concerning religious life, military secrets and catastrophes (Kozieł 2003: 52). Carefully selected programmes promoted socialist realist aesthetics and despised the "muck and trash of bourgeois models" (Kozieł 2003: 50; my translation). Among foreign imports, the artistic output of the partner states dominated over Western productions. These were cherished by the audience as the most desirable luxury good (Bogucka 2002: 167). The serial adventures of Zorro (1957), Sir Lancelot (1956-1957), Dr Kildare (19611966), The Fugitive (1963-1967), Bonanza (1959-1973) and The Saint (1962-1969) took the Polish viewers' breath away, allowing them a glimpse behind the Iron Curtain. Thus, translated programmes touched the lives of millions of Poles, shaping their image of the world outside the socialist camp.

The 1970s witnessed the accession to power of Edward Gierek and the period of sham prosperity in Poland, achieved at the cost of enormous foreign debt. The government started massive borrowing from the West, freezing food prices and pampering the unaccustomed Poles with cars and dishwashers. Television became key in disseminating the propaganda of success (Kozieł 2003: 19). Never before had it been subjected to such rigorous political control. The Party supervised the programme and personnel policy, recruiting television staff from among the most fervent activists. The censors worked shifts to process the average of twenty-five thousand hours of radio and television programme a year (Kozieł 2003: 118).

Interestingly, it was light entertainment that played a crucial political role at the time. It nourished optimistic attitudes, relieved negative emotions and diverted public attention from the spiralling national debt and impending economic crisis (Kozieł 2003: 125). Foreign series enjoyed extraordinary popularity, reaching audience ratings of 60-70\% (Kozieł 2003: 185). Among these, The Forsyte Saga (1967), I, Claudius (1976), Rich Man, Poor Man (1976) and The Saint were the most successful ones.

One might wonder what motivated the communist decision-makers to allow particular Western imports on air. According to Kozieł, the reason was gaps in the Polish repertoire. There was, for instance, a desperate shortage of detective series. The communist broadcasters wished to meet the need with Soviet productions, but the Soviet Embassy in Warsaw issued an official request to restrict the number of films showing delinquency in the USSR. As a consequence, the policy was adopted to broadcast audiovisual programmes which show crime and moral decay in the West (Kozieł 2003: 171). Thus, it seems that the Polish viewers owed their familiarity with The Saint to the native filmmakers' incompetence.

\subsection{Research corpus}

The earliest version of The Saint examined below dates from the period when television exerted the greatest influence on the Poles' lifestyle, attitudes and aspirations, 
creating and perpetuating myths and stereotypes (Kozieł 2003: 183). In the second half of the decade, the economic situation in Poland deteriorated so dramatically that on 24 June 1976 the government increased the prices of food by $60 \%$. This raised a wave of strikes and protests, which resulted in heavy repressions (Lukowski and Zawadzki 2006: 307).

The episodes preserved in the television archives were all translated at that time and broadcast in August and September 1976. The available documentation encompasses three files, which contain dialogue continuity scripts of The Convenient Monster (1966), ${ }^{5}$ The Counterfeit Countess (1967), ${ }^{6}$ and The Man Who Liked Lions (1966), ${ }^{7}$ together with their two Polish versions: a word-for-word rendition by an anonymous translator and its subsequent revision by an editor, Wygodny potwór, Fałszywa hrabina and Człowiek, który lubił lwy, respectively, all broadcast in $1976 .{ }^{8}$

This two-stage procedure of adapting foreign texts for screen was reportedly followed in Polish television until the 1980s (Garcarz 2007: 142). The translator would produce a literal rendition, the so-called surówka [raw material] to be reworked by an editor, who adapted it stylistically and ideologically to the needs of the voiceover artist and the audience. Only the editor's name was mentioned at the end of the programme as the author of the Polish version. Both the literal and revised renditions of the three episodes were analysed. The former reveal traces of unintentional sociocultural manipulation on the part of the translator, who may be seen not only as a tool but also as a victim of the Marxist propaganda. The latter show symptoms of conscious socio-cultural and stylistic manipulation on the part of the editor, who introduced certain stylistic and ideological corrections to the literal surówka.

Another version of The Saint analysed below also comes from the Polish Television archive. It dates from 2000 and shows the evolution of the voiceover technique. Nowadays, the texts are prepared by renowned translators, acknowledged in the credits. They are almost single-handedly responsible for the final outcome, with minor linguistic corrections introduced by copy-editors (Garcarz 2007: 143), who are often translators themselves. The corpus includes two dialogue lists prepared by famous Polish translators Małgorzata Garbalska and Andrzej Chajewski, with sparse corrections by an editor. This material illustrates more recent translation strategies, which involve subtle modernisation and skilful condensation of the original.

The last version under analysis is the latest voiceover translation of The Saint, released on DVD in 2006 and re-issued by GM Distribution in 2008. As the most recent product of the Polish voiceover tradition, it demonstrates some of the new stylistic and socio-cultural approaches to the source text.

Thus, the research corpus, presented in Table 1, encompasses four versions all together: two versions of each of the three episodes created in the communist era, a version of two episodes broadcast on the public television twenty-five years later and my own transcript of the voiced-over episodes released on DVD. 
TABLE 1

Research Corpus

\begin{tabular}{|c|c|c|c|}
\hline $\begin{array}{l}\text { Original } \\
\text { (ITC) }\end{array}$ & $\begin{array}{l}1976 \\
(\text { TVP 1) } \\
\end{array}$ & $\begin{array}{l}2000 \\
(\text { TVP 1) }\end{array}$ & $\begin{array}{l}2006 / 2008 \\
\text { (DVD, GM Distribution) }\end{array}$ \\
\hline $\begin{array}{l}\text { The Convenient } \\
\text { Monster } \\
\text { (1966) }\end{array}$ & $\begin{array}{l}\text { Wygodny potwór } \\
\text { [The Convenient Monster] } \\
\text { Edited by Janina } \\
\text { Małachowska. } \\
\text { Broadcast in } 1976 \text { and } \\
\text { read by Lucjan Szołajski. }\end{array}$ & Unavailable & $\begin{array}{l}\text { Prawdziwy potwór } \\
\text { [The Real Monster] } \\
\text { Translated by Michał } \\
\text { Berger and read by Jacek } \\
\text { Brzostyński. }\end{array}$ \\
\hline $\begin{array}{l}\text { The Counterfeit } \\
\text { Countess } \\
\text { (1967) }\end{array}$ & $\begin{array}{l}\text { Fałszywa hrabina } \\
\text { [The False Countess] } \\
\text { Edited by Janina } \\
\text { Małachowska. } \\
\text { Broadcast on } 7 \text { August } \\
1976 \text { and read by Lucjan } \\
\text { Szołajski }\end{array}$ & $\begin{array}{l}\text { Podstępna hrabina } \\
\text { [The Devious Countess] } \\
\text { Broadcast on } 3 \text { July } 2000 . \\
\text { Translated by Andrzej } \\
\text { Chajewski, edited by } \\
\text { Bohdan Maliborski and } \\
\text { read by Stanisław } \\
\text { Olejniczak }\end{array}$ & $\begin{array}{l}\text { Fałszywa hrabina } \\
\text { [The False Countess] } \\
\text { Translated by Studio } \\
\text { Publishing and read by } \\
\text { Jacek Brzostyński }\end{array}$ \\
\hline $\begin{array}{l}\text { The Man Who } \\
\text { Liked Lions } \\
\text { (1966) }\end{array}$ & $\begin{array}{l}\text { Człowiek, który lubił lwy } \\
\text { [The Man Who Liked } \\
\text { Lions] } \\
\text { Edited by Janina } \\
\text { Małachowska. } \\
\text { Broadcast on } 4 \text { September } \\
\text { 1976) and read by Lucjan } \\
\text { Szołajski }\end{array}$ & $\begin{array}{l}\text { Człowiek, który lubił lwy } \\
\text { [The Man Who Liked } \\
\text { Lions] } \\
\text { Broadcast on } 11 \text { July } 2000 \text {, } \\
\text { translated and edited by } \\
\text { Małgorzata Garbalska }\end{array}$ & $\begin{array}{l}\text { Człowiek, który uwielbiał } \\
\text { lwy } \\
\text { [The Man Who Adored } \\
\text { Lions] } \\
\text { Translated by Alicja } \\
\text { Mołoniewicz and read by } \\
\text { Jacek Brzostyński }\end{array}$ \\
\hline
\end{tabular}

\subsection{Research procedure}

In my analysis of the collected material, I used the assumption that the world presented in the series was so different from the Polish communist reality of 1976, and the Polish capitalist reality of the new millennium that its translation must have involved ideological and cultural deformation. I therefore compared the original dialogue with the Polish transcripts, looking for traces of socio-cultural manipulation. In the oldest versions, I focused on the Polish authors' attempts to socialise capitalism, modelling it on the Soviet reality. In the more recent versions, I concentrated on their efforts to modernise capitalism and reduce the anachronism of the series in the eyes of the contemporary Polish audience.

Below, I organise my observations around these two central issues. Firstly, I focus on the life of The Saint in the 1970s. I discuss symptoms of socio-cultural manipulation in the communist representation of capitalist reality. To justify my diagnosis, I juxtapose the older solutions with the more recent ones, each representing a different economic and ideological perspective. Subsequently, I focus on the life of The Saint in the new millennium. I analyse traces of socio-cultural manipulation in contemporary approaches to the dated original, again following the same contrastive procedure.

\section{Socialising Capitalism}

While approaching the oldest Polish versions of The Saint, I deliberately look for traces of communist ideology that reveal and overlook other interesting features. 
Taking into account its social, discourse and cognitive aspects (Munday 2008: 44); i.e., the prevalent power structure, forms of expression and modes of perception it imposed, I try to find out how pervasive the ideology was, which aspects of the original dialogue lists it affected and what techniques were used to promote it, skewing the Anglophone message to the needs of political propaganda.

As it turns out, the deformations are very subtle and seem to reflect rather than consciously shape the communist mindset. The translators and editors were both victims and perpetrators of indoctrination. What attracts particular attention in their portrayal of the Western reality is sensitivity to class distinctions and material inequalities, preference for collectivism over individualism and a tendency to project domestic patterns of social interactions onto the foreign original.

\subsection{Sensitivity to class struggle}

The analysed episodes of The Saint feature characters from various social backgrounds: petty criminals and poachers, farmers and domestic servants, police officers and academics, journalists, artists and aristocrats. Since class conflict was at the core of the communist propaganda, the portrayal of social relations posed a challenge to the earliest translators, encouraging various manipulative practices. Let me comment on two: those of projection and caricature.

\subsubsection{Projection of social divisions}

The earliest translation often projects upon the Western social system the class distinctions popularised by the communist propaganda. It therefore reveals the interference of the dominant discourse used to express Marxist ideology in Polish society. For example, in the introduction to The Convenient Monster, the narrator mentions reports on the existence of the Loch Ness Monster:

(1) The witnesses, all denying any contact with the national beverage, were from all walks of life... from castles... to cottages.

(The Convenient Monster 1966)

The 1976 version uses formal register and explicates the social stratification of the teetotallers, expressly mentioning arystokracji [aristocracy] and wieśniaków [peasants]:

(2) Wszyscy zapewniają, że nie pili wtedy napojów wyskokowych. Reprezentowali różne środowiska - od arystokracji do wieśniaków.

[They all profess that they did not drink any alcoholic drinks at the time. They represented various milieus - from aristocracy to peasants.]

(Wygodny potwór 1976, edited version; my translation)

Thus, instead of alluding to the elements of the Scottish landscape, the Polish narrator describes the Scottish social structure, speaking with the voice of the communist propaganda. The more recent version, by contrast, preserves the original metonymy and disregards the problem of social stratification, focusing instead on the issue of the national beverage: 
(3) Świadkowie zgodnie wypierali się bliższych kontaktów z mocnym narodowym trunkiem, zarówno w zamkach, jak i w wiejskich chałupach.

[The witnesses unanimously deny any contact with the strong national beverage, both inside the castles and in peasant cottages.]

(Prawdziwy potwór 2006-2008; my translation)

In another episode, The Man Who Liked Lions, a different problem emerges - that of portraying bourgeoisie. Talking about a series of suspicious murders, Simon Templar remarks:

(4) Harold Rendrew, one of America's leading industrialists, was fighting a strike when he drove his car smack bang into a brick wall.

(The Man Who Liked Lions 1966)

In the 1976 literal rendition, the translator transforms the leading industrialists into strike leaders, using the clichéd term przodujący działacz [leading activist]. The editor modifies this version, using another ritualised image of an industrial activist:

(5) Harold Renfrew [sic], jeden z przodujących działaczy w przemyśle amerykańskim. Stoi na czele strajku. Tego dnia właśnie wjeżdża swoim samochodem w mur.

[Harold Renfrew, one of the leading activists in American industry. He is leading a strike. On that very day he drives his car into a wall.]

(Człowiek, który lubił lwy 1976, literal version; my translation)

(6) Harold Renfrew [sic], działacz przemysłowy, stoi na czele strajku. Tego dnia właśnie wjeżdża samochodem w mur.

[Harold Renfrew, an industrial activist, is leading a strike. On that very day he drives his car into a wall.]

(Człowiek, który lubił lwy 1976, edited version; my translation)

Both authors substitute the enemies of the people with their friends in order to domesticate the foreign reality. They also reveal a weakness for stylistic clichés, categorising the foreign social spectrum along domestic lines. The DVD, created decades later, also portrays the character as a strike leader (7) and only in the recent television translation (8) does he preserve the identity of the company owner:

(7) Harold Rendrew, jeden z wielkich amerykańskich przywódców strajkujących robotników wjechał samochodem na betonową ścianę.

[Harold Rendrew, one of the greatest American leaders of the striking workers drove his car into a concrete wall.]

(Człowiek, który uwielbiał lwy 2006-2008; my translation)

(8) Strajk w przedsiębiorstwie Harolda Rendrew. Jego rozpędzony samochód wjeżdża w mur.

[Strike in the company of Harold Rendrew. His speeding car hits against a wall.] (Człowiek, który lubił lwy 2000; my translation)

\subsubsection{Caricature of social divisions}

In order to emphasise class struggle, the first translators also resorted to caricature, presenting bourgeois protagonists as more corrupt than they appear in the original. Thus, they reflected both social, discourse and cognitive aspects (Munday 2008: 44) of communist ideology in their rendition. For instance, when the character of Principessa Alexandra Castrivini appears in one of the episodes, she is described 
as a fool in the original and - more contemptuously - as an idiot/lunatic (idiotka/ wariatka) in the communist versions. The more recent translations are more lenient towards her:

(9) She is really very sweet. / Oh, she's a fool. / But harmless...

(The Man Who Liked Lions 1966)

(10) Ona jest naprawdę przemiła. / Och, to idiotka/wariatka. / Ale nieszkodliwa... [She is indeed very kind. / Oh, she's an idiot/a lunatic. / But harmless...]

(Człowiek, który lubił lwy 1976, literal version; my translation)

(11) Ona jest przemiła. / Wariatka. / Ale nieszkodliwa...

[She is indeed very kind. / A lunatic. / But harmless...]

(Człowiek, który lubił lwy 1976, edited version; my translation)

(12) Jest bardzo miła. / Raczej niemądra. / Zupełnie nieszkodliwa.

[She is very kind. / Rather silly. / Completely harmless.]

(Człowiek, który lubił lwy 2000; my translation)

(13) Jest urocza. / Jest głupia. / Ale niegroźna.

[She is enchanting. / She is stupid. / But harmless.]

(Człowiek, który uwielbiał lwy 2006/2008; my translation)

The working classes, by contrast, enjoy greater reverence in the archive sources than they do in the more recent ones. For example, when a Scottish housekeeper complains in The Convenient Monster that she deserves more respect from her employers, the image of their mutual relations becomes exaggeratedly feudal in the communist version and surprisingly modern in the recent DVD version:

(14) I've worked in this house forty years. I've nursed Master Noel as a baby. I sat at his sainted mother's deathbed. After all that I think that I've a perfect right to expect some consideration. / You've no rights at all Mrs. Moncrief. You're only his housekeeper. She's his wife.

(The Convenient Monster 1966)

(15) Pracuję tu czterdzieści lat. Niańczyłam panicza Noela. Czuwałam przy łożu śmierci jego matki. Mam tu chyba jakieś prawa. / Nie. Pani jest tylko jego gospodynią a ona żoną.

[I've worked here for forty years. I've taken care of Master Noel. I waited at his mother's deathbed. I have some rights here. / No. You (polite form of address) are only his housekeeper and she is his wife.]

(Wygodny potwór 1976, edited version; my translation)

(16) Pracuję w tym domu od 40 lat. Byłam nianią pana Noela. Czuwałam przy jego zmarłej matce. Mam prawo do odrobiny szacunku. / Jesteś gosposią, a ona żoną. [I've worked in this house for forty years. I was Mr Noel's nanny (diminutive). I watched over his late mother. I have a right for some respect. / You (direct form of address) are a housekeeper (diminutive) and she is his wife.]

(Prawdziwy potwór 2006/2008; my translation)

In the earlier version, Mrs Moncrief uses literary and archaic forms, niańczyć [take care] and panicz [master], which emphasise her respectability and highlight unjust treatment by her aristocratic employers. She is also addressed by Angus, her interlocutor, with a polite, indirect form pani. Thus, the housekeeper is presented as hardworking and praiseworthy and Master Noel's family as unpleasant and exploitive. 
The contemporary translator, by contrast, modelled Mrs Moncrief's status on that enjoyed by contemporary domestic help. She is portrayed as niania and gosposia, two diminutive forms used nowadays in Polish to describe babysitters and housekeepers, respectively. She uses neutral register and retains professional rather than feudal relations with her employers. She refers to her former ward as Pan Noel [Mr. Noel], in accordance with contemporary Polish norms. Angus, in turn, addresses her directly, with a casual second-person form, which implies a small power distance between them.

\subsection{Promotion of collectivism}

Another reason for socio-cultural manipulation was the incompatibility of Western individualism and the utopian Soviet collectivism, which encouraged the first translators to adjust the original to the communist ideals of selflessness.

For instance, in The Man Who Liked Lions, the main villain craves the return of the Roman Empire. Looking at a stylised portrait of a man who resembles an ancient hero, he exclaims:

(17) A marvellous archetype... The sort of man who raised Rome to the peak of her power.

(The Man Who Liked Lions 1966)

The literal translation of this line from 1976 bears suspicious resemblance to Trotsky's definition of the New Communist Man, i.e., a "superman" who will "raise himself to a new plane" and "create a higher social biologic type" (Trotsky 1924):

(18) Cudowny nad-człowiek. Taki właśnie ludzki gatunek podniósł Rzym do szczytu potęgi.

[A marvellous super-man. Such human species raised Rome to the peak of her power.]

(Człowiek, który lubił lwy 1976, literal version; my translation)

The original "archetype" is substituted with the philosophical notion of a "superman." An individual hero transforms into a collective human species. As the literal translation was clumsy and aggressively ideological, it was subsequently toned down by the editor, who deleted the philosophical references, but highlighted the collective effort of Roman heroes:

(19) Tacy ludzie jak on podnieśli kiedyś Rzym do szczytu potęgi.

[Once people like him raised Rome to the peak of her power.]

(Człowiek, który lubił lwy 1976, edited version; my translation)

The later voiceover versions faithfully reflect the individualist ideals of the original:

(20) To archetyp człowieka, który wyniósł Rzym na szczyty władzy.

[That is the archetype of a man who raised Rome to the heights of her power.]

(Człowiek, który lubił lwy 2000; my translation)

(21) Doskonały archetyp. Typ mężczyzny, który wyniósł Rzym na szczyty potęgi. [A perfect archetype. A type of man (masculine), who raised Rome to the heights of power.]

(Człowiek, który uwielbiał lwy 2006/2008; my translation) 
Interestingly, while all television versions treat the "man/humanity" generically, the DVD version emphasises the heroic "male," alluding to the contemporary masculinity crisis. Consequently, when the original mentions the pale grey flabbiness of man today (The Man Who Liked Lions 1966), all television versions bemoan szarzyzna codziennego życia, ludzkość słaba, nieporadna [the greyness of everyday life; the weakness, ineptitude of mankind] (Człowiek, który lubił lwy 1976; my translation) or współczesna nijakość i ślamazarność [contemporary dullness and sluggishness] (Człowiek, który lubił lwy 2000; my translation), whereas the DVD translation complains about bladość i zwiotczałość współczesnego mężczyzny [the paleness and flabbiness of a contemporary male] (Człowiek, który uwielbiał lwy 2006/2008; my translation). This is an example of modern socio-cultural manipulation, which uses the original as a pretext to air contemporary social frustrations.

\subsection{Demonisation of capitalism}

Apart from emphasising class struggle and collectivism, other manipulation techniques in the earliest translation were aimed at perpetuating negative stereotypes of capitalist society.

\subsubsection{Caricature of bourgeoisie}

Under the communist regime, egalitarianism was considered the highest social value and excessive affluence was held in official contempt. Hence, the translators tried to tone down the capitalist worship of wealth presented onscreen. They caricatured rich characters and avoided any verbal allusions to the luxuries unavailable in Poland.

An interesting example of such an intervention involves both conscious manipulation and unconscious blunder. In The Counterfeit Countess (1966), Simon Templar is treated to champagne by a sham millionaire. Invited to his table, Simon exclaims: What a marvellous idea, to which his interlocutor responds, I am full of them. The communist author of the literal translation (22) misunderstood the original and produced an incoherent dialogue exchange. The editor (23) was thus forced to improvise and the millionaire brags about having forsy jak lodu [loads of money], instead of mentioning "lots of ideas." As a consequence, he looks even more degenerate than in the original, which strengthens prejudice against the capitalist shark:

(22) Wspaniały pomysł. / Mam tego jak lodu...

[An excellent idea. / I have loads of it.]

(Fałszywa hrabina 1976, literal version; my translation)

(23) Wspaniały pomysł. / Mam forsy jak lodu.

[An excellent idea. / I have loads of money.]

(Fatszywa hrabina 1976, edited version; my translation)

(24) Wspaniały pomysł. / Mam ich mnóstwo.

[An excellent idea. / I have a whole host of them.]

(Podstępna hrabina 2000 and Fałszywa hrabina 2006/2008; my translation)

A few moments later, when the villain orders more champagne, Templar compliments him on his generosity and, upon learning that his benefactor "has just concluded a most important business deal," he responds in an old-boy fashion: 
The 1976 version consistently eradicates all traces of solidarity with the businessman, however insincere or ironic they might be. Simon Templar distances himself from his interlocutor, using the word forsa $[d o s h]$, which sounds slightly pejorative in Polish:

(26) Jest pan hojny. / Zrobiłem świetny interes. / Grunt to forsa...?

[You're generous. / I've just made a great deal. / Dosh is the main thing, isn't it?] (Fałszywa hrabina 1976, edited version; my translation)

(27) Ładny gest. / Zrobiłem dobry interes. / Nie ma to jak interesy. [A nice gesture. / I've made a good deal. / Nothing like good deals, is there?]

(Podstępna hrabina 2000; my translation)

(28) Ma pan gest. / Ubiłem dobry interes. / Nie ma to jak robienie pieniędzy. [You're open-handed. / I've finalised a good deal. / Nothing like making money, is there?]

(Fatszywa hrabina 2006/2008; my translation)

In the remaining versions, Templar pretends sympathy with the villain, allowing the audience to uncover his ulterior motives. But the earliest rendition prefers to make the politically correct message clear, instead of relying on implied meaning and irony.

\subsubsection{Neutralisation of prosperity}

Apart from exaggerating capitalist corruption, the earliest translators quite often tone down the allusions to material comfort and prosperity, either neutralising or omitting them. For example, when Simon Templar is encouraged in The Convenient Monster (1966) to abandon his lodgings in a local pub for the luxuries of a country house, the precise description of the comforts (great soft beds and central heating) disappears from the 1976 edited version.

\subsection{Secularisation and materialism}

A different aspect of socio-cultural manipulation has to do with religious references. The communist party aimed at maximal secularisation of public and private life. Hence, the translators either avoided religious allusions or abused them to create a distorted image of piety.

\subsubsection{Modification of religious allusions}

In the analysed material, certain religious allusions disappear from the communist version, although they performed a purely rhetorical function in the original. For example, in The Counterfeit Countess (1967) the biblical "good Samaritan," present in the literal translation, is substituted with the neutral dobroczyńca [benefactor] in the revised text.

Another manipulation technique involves the change of axiological commitment. Thus, when in the same episode Simon Templar comments jocularly Don't stop Darling. Confession's good for the soul, the earliest authors immediately distance themselves from this statement, adding the adverb podobno [allegedly]: 
(29) Spowiedź podobno oczyszcza duszę...

[Confession of sin allegedly clears the soul.]

(Fałszywa hrabina 1976, literal and edited version; my translation)

(30) Spowiedź przynosi ulgę.

[Confession of sin brings relief.]

(Podstępna hrabina 2000; my translation)

(31) Wyznania koją duszę...

[Confessions bring relief to the soul.]

(Fatszywa hrabina 2006/2008; my translation)

Quite interestingly, the most recent translation reveals secular bias in a different form. It neutralises the religious connotation present in the original, turning spowiedź [confession of sin] into wyznania [confessions] (Example 31).

\subsubsection{Generalisation}

Another technique, that of generalisation, was used for manipulative purposes to misrepresent a character in The Convenient Monster (1966), who was portrayed there as a despicable bigot. According to the harsh words of his daughter, He's a Bible thumping puritanical old fool.

Under the communist regime, no demonstration of religious beliefs was welcome and the notion of "Bible-thumping Christians" aggressively forcing their creed upon others must have seemed unthinkable. Hence, the author of the literal translation used periphrasis to transform extrovert piety into introvert idolatry, calling the man:

(32) To zaczytany w Biblii purytański stary dureń.

[He's a Bible-idolizing puritan old fool.]

(Wygodny potwór 1976, literal version; my translation)

The editor, however, used this opportunity to generalise the image. Deleting the pejorative old fool, she portrayed the apparently despicable character in a more universal way, possibly applicable to all Christians:

(33) To wychowany na Biblii purytanin.

[He's a puritan raised on the Bible.]

(Wygodny potwór 1976, edited version; my translation)

This manipulative strategy contrasts sharply with the most recent rendition, which strengthens the negative expressive load of the daughter's utterance, but tones down the religious connotation:

(34) Przeklęty purytański głupiec.

[Damned puritanical fool.]

(Prawdziwy potwór 2006/2008; my translation)

Again, this might suggest a more consistent tendency on the part of the DVD translator to neutralize the original religious allusions.

\subsubsection{Mistranslation}

The secularisation of the Soviet Bloc had its philosophical foundation in materialism. The most amusing example of ideological manipulation related to this issue resulted from a misunderstanding rather than deliberate effort. It makes me suspect, however, 
that blunder might have been quite a prolific source of socio-cultural distortions. In The Convenient Monster, one of the characters expresses his views on Nessie theory:

(35) I don't know what to believe. On one hand there is my wife. She's rather a distinguished naturalist and she's convinced that this monster exists.

(The Convenient Monster 1966)

As it turned out, the term naturalist confused the earliest translator, who - apparently saturated with Marxist ideology - associated it with philosophical denial of the supernatural rather than professional interest in biology, which was indeed the case. Hence, the unedited version reads:

(36) Sam nie wiem, w co wierzyć. Poza tym istnieje moja żona. Ona jest raczej naturalistką / materialistką, a jest przekonana o istnieniu tego potwora.

[I don't know what to believe myself. Besides, there exists my wife. She is rather a naturalist / materialist and yet she is convinced of the monster's existence.]

(Wygodny potwór 1976, literal version; my translation)

As the utterance was quite complex and unfit for the mass audience, it was transformed in post-edition. The philosophical naturalistka / materialistka [naturalist / materialist] was described as osoba rozsądna [a sensible person]:

(37) Sam nie wiem. Moja żona to osoba rozsądna, a jest przekonana o jego istnieniu. [I'm not sure myself. My wife is a sensible person and she is convinced of its existence.]

(Wygodny potwór 1976, edited version; my translation)

Here, the editor did not take the opportunity to promote the prevalent philosophical doctrine, which was offered by an unsuspecting translator. But the pervasive influence of the Homo Sovieticus mentality on several automatic choices in the earliest translation becomes all the more apparent when contrasted with the contemporary version of the same utterance:

(38) Sam nie wiem, w co wierzyć. Moja żona, uczony biolog, jest pewna że on istnieje. [I don't know what to believe. But my wife, a learned biologist, is sure that it exists.]

(Prawdziwy potwór 2006/2008; my translation)

\subsection{Domestication of social relations}

What also strikes the contemporary reader of the earliest translation of The Saint is the modelling of foreign social interactions on domestic patterns. It becomes especially visible in the skewed attitudes towards authorities and towards the press, as well as in the portrayal of professional relationships.

The most consistent manipulative strategy visible in the analysed episodes was aimed at promoting respect for authorities, however despicable or corrupt they were in the original. That was a real challenge, as Simon Templar treats police officers with superior leniency at best. Yet the earliest authors managed to tone down his impertinence, choosing polite forms of address and curbing his sarcasm.

For example, when Simon decides to retrieve his passport, confiscated by a corrupt Italian policeman, he demands in the original, my passport (The Man Who Liked Lions 1966). The 1976 version uses a polite form of request, preserving power distance, whereas the later versions choose more audacious solutions: 
(39) Mogę prosić o paszport?

[May I have my passport, please?]

(Człowiek, który lubił lwy 1976, literal and edited version; my translation)

(40) Proszę paszport.

[Passport, please.]

(Człowiek, który lubił lwy 2000; my translation)

(41) Mój paszport.

[My passport.]

(Człowiek, który uwielbiał lwy 2006/2008; my translation)

Respect for authorities contrasted with disdain for the concept of free press. Thus, when in The Man Who Liked Lions (1966) an assassinated journalist is mentioned who would give anything for a story, the Polish versions reveal changing attitudes towards the reporter's curiosity:

(42) Tony oddałby wszystko za sensację dla prasy.

[Tony would give anything for a press sensation.]

(Człowiek, który lubit lwy 1976, literal and edited versions; my translation)

(43) Dla artykułu poświęciłby wszystko.

[For an article he would give anything.]

(Człowiek, który lubił lwy 2000; my translation)

(44) Gotów oddać wszystko dla sprawy. Nawet życie.

[He was ready to give anything for a cause. Even his life.]

(Człowiek, który uwielbiał lwy 2006/2008; my translation)

Thus, the earliest translation accuses a positive character of sensationalism, although we know that he was trying to uncover a dangerous conspiracy. In the most recent version, by contrast, he is portrayed as a selfless idealist fighting for a cause.

\subsection{Domestication of cultural references}

The series naturally presented various aspects and products of Western culture which were unavailable to the Polish audience. In the earliest translation, verbal references to food, drink, buildings, meals, and games were all substituted with domestic functional equivalents or omitted. Thus bingo transformed into Wielka Gra, a popular game show on Polish television, lunch transformed into the Polish obiad [dinner], pub into gospoda [country tavern] and nut bread into the Polish placek [cake]. Quite interestingly, all proper names, weights and measures were transferred in the original form, although the Polish audience, accustomed to the metric system, might have had problems imagining a 17-inch footprint of the Loch Ness Monster. More recent translations, by contrast, preserved some of the popular internationalisms, i.e., bingo and lunch and transferred most of the proper names and brand names to emphasise the foreign setting of the original. The applied techniques, however, have not changed significantly over the years.

\section{Modernising Capitalism}

Owing to subtle distortions of the original dialogue, the earliest translators managed to adapt the image of the Western reality to the demands of prevalent ideology. Yet, 
as the analysis demonstrates, the recent versions of The Saint have also revealed traces of socio-cultural manipulation. With the changing political and economic situation in Poland, the needs of the Polish audience have changed, too (Bogucka 2002). After the fall of the Iron Curtain, the Polish culture grew more and more Westernised, with an influx of foreign products and customs. From a contemporary perspective, The Saint may come across as naïve and outmoded, which may justify why the contemporary translation(s) of the series also resort to socio-cultural manipulation.

We have already discussed a few examples, where the author of the DVD version adjusted the verbal message to express current attitudes towards domestic help (Example 16), journalism (Example 44) and masculinity crisis (Example 21).

Other subtle modifications which can be noticed concern skewing the temporal perspective to de-emphasise those events and inventions, which were presented as current in the film and which are out of date today. Thus, when Simon Templar remarks in one of the episodes, I am pressing that we join the Common Market immediately, both contemporary translators present him simply as a supporter of the Common Market, avoiding any temporal references to Britain's status in the European Economic Community.

Another aspect toned down is the sensationalism with which the outmoded technological innovations are mentioned. When Simon exclaims proudly, I've been a very busy boy on the transatlantic telephone (The Man Who Liked Lions 1966), only the 1976 translation shares his enthusiasm. The remaining versions brush it off with more casual remarks, such as the metonymical phone calls to the States, which sound natural in contemporary Polish:

(45) Telefonowałem aż za Atlantyk.

[I've telephoned as far as beyond the Atlantic.]

(Człowiek, który lubił lwy 1976, literal and edited version; my translation)

(46) Przeprowadziłem kilka rozmów telefonicznych ze Stanami.

[I've made a few phone calls to the States.]

(Człowiek, który lubił lwy 2000; my translation)

(47) Spędziłem kilka pracowitych godzin na transatlantyckich rozmowach. I've spent a few busy hours making transatlantic conversations.

(Człowiek, który uwielbiał lwy 2006/2008; my translation)

What should also be mentioned is the consistent lowering of register in the most contemporary DVD version, which reflects current communicative trends in Poland. Unlike the translation prepared in 2000 for the state television, the most recent DVD version portrays social interactions more sloppily and informally than they appear in the original. The characters sometimes disregard the Polish rules of decorum, using vulgarisms or addressing relatively unfamiliar interlocutors in the secondperson singular forms (Example 16). These traces of modernisation, however, and their socio-cultural motivation, merit a separate analysis beyond the scope of this article.

\section{Conclusion}

In my analysis, I drew on the heritage of descriptive translation studies, comparing revised drafts of the oldest translations with subsequent renditions by other authors 
(Toury 1995/2009: 209). I tried to find out how each translator's ideology, succinctly defined by Munday (2008: 48) as his or her "experience, thoughts and beliefs as an actor in a particular socio-cultural and historical site," affected the portrayal of the filmic world.

Apparently, the three lives of The Saint, narrated by subsequent generations of translators differ from each other on social and poetic levels. The communist audience admired a bright, exotic reality presented onscreen, and listened to the conversations which partly echoed the prevalent socio-political propaganda. The positive characters were quite respectful towards authorities, praised collectivism over individualism, criticised corruption and materialism and avoided touchy issues, such as prosperity or religion. The villains, by contrast, resembled stereotypical enemies of the people: rapacious capitalists and pretentious aristocrats.

This domesticating effect was achieved via multiple manipulation techniques such as projecting familiar values onto foreign reality, caricaturing its aspects, introducing axiological distance, substituting, generalising or omitting cultural references. Only some of those distortions seem to be deliberate. Others may be said to strike at subconscious products of the Homo sovieticus mentality, or evidence of pure ignorance, most likely justified by the lack of appropriate resources and cultural exchange.

The Polish television audience at the dawn of the new millennium enjoyed the cult film with a voiceover rendition that respected the original realities, but smoothed away minor temporal incongruities. From a critical perspective, it embodies voiceover at its best and is worth examining in terms of stylistic manipulation, i.e., skilful handling of the original material to adapt it to the technical requirements of the voice artist, as well as cultural and aesthetic requirements of the audience. The viewers of the most recent DVD edition, by contrast, are confronted with the classic characters, who follow fashions of the 1960s and communicative patterns of today.

The above analysis demonstrates various ways of socialising and modernising capitalism, devised by translators in order to meet the needs and constrains of the changing socio-political situation in Poland. Brief and precursory, it should certainly be consolidated with other related case studies (Munday 2008: 16) in order to draw more general conclusions on the changing notion of acceptability in the Polish television translation. What also deserves to be further explored is the possibility of capitalising on the fifty-year tradition of voiceover translation in Poland to perfect this idiosyncratic technique. The comparison of consecutive versions of The Saint has already brought to light the emergence of new translation strategies, presumably aimed at adjusting the text to the needs of a successful voiceover performance for a different audience. They certainly call for a more detailed investigation in the future.

\section{ACKNOWLEDGMENTS}

I would like to express my gratitude to Tomasz Bujak and Monika Gabryś from The Centre of Documentation and Programme Resources (Ośrodek Dokumentacji i Zbiorów Programowych) of the Polish Television for kindly allowing me to use the Polish Television archive.

\section{NOTES}

1. The Saint, series (1962-1969): Starring Roger Moore. Produced by Robert Baker and Monty Berman, New World and Bamore. Distributed by ITC Entertainment. 
2. Swięty [The Saint] series broadcast by the Polish Television in the 1960s and the 1970s (Kozieł 2003: 95, 172). Translated dialogue lists of three episodes (1976) deposited in the Polish Television archive.

3. Święty [The Saint] series broadcast by the Polish Television in 2000 and 2001. Dialogue lists translated by Andrzej Chajewski, Małgorzata Garbalska and Bohdan Maliborski deposited in the Polish Television archive.

4. Święty-sezon 1 (edycja specjalna) [The Saint - Season 1 (Special Edition)] (2006/2008) and Święty - sezon 2 (edycja specjalna) [The Saint - Season 2 (Special Edition)] (2006/2008). Distributed by GM Distribution.

5. The Saint - The Convenient Monster (4 November 1966): Directed by Leslie Norman. Visited on 30 June 2012, <http:// http://www.tv.com/shows/the-saint/the-convenient-monster-135079/>.

6. The Saint - The Counterfeit Countess (3 March 1967): Directed by Leslie Norman. Visited on 30 June 2012, <http:// http://www.tv.com/shows/the-saint/the-counterfeit-countess-133007/>.

7. The Saint - The Man Who Liked Lions (18 November 1966): Directed by Jeremy Summers. Visited on 30 June 2012, <http:// http://www.tv.com/shows/the-saint/the-man-who-liked-lions-135081/>.

8. Wygodny potwór [The Convenient Monster] (1976); Fatszywa hrabina [The False Countess] (1976) and Człowiek, który lubił lwy [The Man Who Liked Lions] (1976). Translated dialogue lists with handwritten corrections by the editor deposited in the Polish Television archive.

\section{REFERENCES}

Bogucka, Teresa (2002): Triumfujące profanum. Telewizja po przełomie 1989 [Triumphant Profane. Television after the 1989 Turnover]. Warsaw: Sic!

Bukowski, Piotr and Heydel, Magda, eds. (2009): Współczesne teorie przekładu. Antologia [Contemporary Theories of Translation. An Anthology]. Krakow: Znak.

Díaz Cintas, Jorge (2003): Teoría y práctica de la subtitulación: inglés-español. Barcelona: Ariel.

Even-Zohar, Itamar (1978/2000): The position of translated literature within the literary polysystem. In: Lawrence Venuti, ed. The Translation Studies Reader. London / New York: Routledge, 192-197.

Garcarz, Michał (2007): Przekład slangu w filmie [Slang Translation in Film]. Krakow: Tertium.

KozieŁ, Andrzej (2003): Za chwilę dalszy ciąg programu... Telewizja Polska czterech dekad 1952-1989 [Regular Broadcasting Will Resume Shortly... Polish Television of the Four Decades 1952-1989]. Warszawa: ASPRA-JR.

Lefevere, André (1982/2000): Mother Courage's cucumbers. In: Lawrence Venuti, ed. The Translation Studies Reader. London / New York: Routledge, 233-249.

Lukowski, Jerzy and Zawadzki, Hubert (2006): A Concise History of Poland. Second Edition. Cambridge: Cambridge University Press.

Munday, Jeremy (2008): Style and Ideology in Translation. Latin American Writing in English. New York / London: Routledge.

Tomaszkiewicz, Teresa (2008): Przekład audiowizualny [Audiovisual Translation]. Warsaw: Wydawnictwo Naukowe PWN.

Toury, Gideon (1978/2000): The nature and role of norms in translation. In: Lawrence VENUTI, ed. The Translation Studies Reader. London / New York: Routledge, 198-211.

Toury, Gideon (1995/2009): Metoda opisowa badań przekładu. [Constituting a Method of Descriptive Studies]. (Translated by Agata SAdZA) In: Piotr Bukowski and Magda Heydel, eds. Współczesne teorie przekładu. Antologia [Contemporary Theories of Translation. An Anthology]. Krakow: Znak, 203-222.

Troтsкy, Leon (1924/1925): Literature and Revolution. (Translated by Rose STrunsky) Visited on 1 May 2011, <http://www.marxists.org/archive/trotsky/1924/lit_revo/ch08.htm>.

Tүмосzко, Maria (2007): Enlarging Translation, Empowering Translators. Manchester/Kinderhook: St. Jerome.

Woźniak, Monika (2008): Jak rozmawiać z kosmitami? Kilka uwag o tłumaczeniu lektorskim telewizyjnych filmów fantastyczno-naukowych [How to Speak with Aliens? A Few Remarks on the Voiceover Translation of Science-Fiction Television Films]. Przekładaniec. 1(20):50-88. 